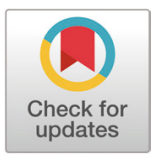

Received: Dec 16, 2019

Revised: Mar 12, 2020

Accepted: Mar 15, 2020

\#These authors contributed equally to this work

${ }^{*}$ Corresponding author

Minho Song

Division of Animal and Dairy Science,

Chungnam National University,

Daejeon 34134, Korea.

Tel: +82-42-821-5776

E-mail:mhsong@cnu.ac.kr

Hyeun Bum Kim

Department of Animal Resources

Science, Dankook University,

Cheonan 31116, Korea.

Tel: +82-41-550-3653

E-mail: hbkim@dankook.ac.kr

Copyright (๑) 2020 Korean Society of Animal Sciences and Technology.

This is an Open Access article distributed under the terms of the

Creative Commons Attribution

Non-Commercial License (http://

creativecommons.org/licenses/by-

nc/4.0/) which permits unrestricted

non-commercial use, distribution, and

reproduction in any medium, provided

the original work is properly cited.

ORCID

Jeong Jae Lee

https://orcid.org/0000-0002-3455-0102

Jeehwan Choe

https://orcid.org/0000-0002-7217-972X

\section{Dietary protease improves growth rate and protein digestibility of growing-finishing pigs}

Jeong Jae Lee ${ }^{1 \#}$, Jeehwan Choe ${ }^{2 \#}$, Joowon Kang ${ }^{1 \#}$, Jin Ho Cho ${ }^{3 \#}$, Sangwoo Park1, Rider Perez-Maldonado ${ }^{4}$, Jee-Yeon Cho ${ }^{5}$, II-Hun Park ${ }^{5}$, Hyeun Bum Kim ${ }^{6 *}$ and Minho Song ${ }^{1 *}$

${ }^{1}$ Division of Animal and Dairy Science, Chungnam National University, Daejeon 34134, Korea

${ }^{2}$ Department of Beef Science, Korea National College of Agriculture and Fisheries, Jeonju 54874, Korea

${ }^{3}$ Division of Food and Animal Science, Chungbuk National University, Cheongju 28644, Korea

${ }^{4}$ DSM Nutritional Products Asia Pacific, Mapletree Business City 117440, Singapore

${ }^{5}$ DSM Nutrition Korea Ltd., Seoul 06675, Korea

${ }^{6}$ Department of Animal Resources Science, Dankook University, Cheonan 31116, Korea

\section{Abstract}

This research was performed to investigate the hypothesis that dietary mono-component protease (PRO) might improve growth performance, nutrient digestibility, and carcass characteristics of growing-finishing pigs. A total of eighty-four pigs [Duroc $\times$ (Landrace $\times$ Yorkshire), $25.3 \pm 2.16 \mathrm{~kg}$ initial body weight] were randomly assigned to three dietary treatments $(7$ replicates/treatment; 2 barrows and 2 gilts/replicate) in a randomized complete block design (block = sex). The dietary treatments were prepared as follows; (1) a positive control (PC) as a typical growing-finishing diet based on corn and soybean meal, (2) PC added with $0.015 \%$ of PRO (PCPRO), and (3) a negative control (NC) added with $0.015 \%$ of PRO (NCPRO). The NC had a lower concentration of crude protein (CP) compared with PC. The PRO was a commercial product that contained 75,000 protease units/g and derived from Nocardiopsis prasina produced in Bacillus licheniformis. Dietary treatments were offered to pigs during growing and finishing periods. Measurements were growth performance, apparent total tract digestibility (ATTD) of nutrients, and carcass characteristics. The PCPRO and/or NCPRO increased average daily gain (ADG) and gain to feed ratio (G:F) during growing $(p<0.10)$, finishing $(p<0.05)$, and growing-finishing periods $(p<0.10)$ compared with PC. Furthermore, pigs fed PCPRO and NCPRO had higher $(p<0.05)$ ATTD of CP and energy during growing and/or finishing periods than those fed PC. In conclusion, the supplementation of PRO in diets improved growth performance and protein digestibility of growing-finishing pigs.

Keywords: Carcass characteristics, Dietary protease, Growing-finishing pigs, Growth performance, Nutrient digestibility

\section{INTRODUCTION}

One of the main goals in swine production is to maximize pork productivity. Consequently, the swine industry constantly requires efficient livestock and nutritional management to increase growth perfor- 
Joowon Kang

https://orcid.org/0000-0001-7340-1479

Jin $\mathrm{Ho}$ Cho

https://orcid.org/0000-0001-7151-0778

Sangwoo Park

https://orcid.org/0000-0003-2288-1374

Rider Perez-Maldonado

https://orcid.org/0000-0001-7695-5258

Jee-Yeon Cho

https://orcid.org/0000-0002-7067-1841

II-Hun Park

https://orcid.org/0000-0003-0851-4180

Hyeun Bum Kim

https://orcid.org/0000-0003-1366-6090

Minho Song

https://orcid.org/0000-0002-4515-5212

Competing interests

No potential conflict of interest relevant to

this article was reported.

\section{Funding sources}

The present study was supported

by the Individual Basic Science \&

Engineering Research Program (No. NRF-

2019R1F1A1063306) through the National

Research Foundation of Korea (NRF) funded

by the Ministry of Education and supported

throughout by DSM Nutrition Korea Ltd.,

Seoul, Korea and DSM Singapore Nutritional

Products.

Acknowledgements

Not applicable.

Availability of data and materia

Upon reasonable request, the datasets

of this study can be available from the

corresponding author.

Authors' contributions

Conceptualization: Choe J, Perez-Maldonado R, Park IH, Song $M$.

Data curation: Lee JJ, Kang J, Park S.

Formal analysis: Lee JJ, Choe J, Cho JY, Park $\mathrm{IH}$.

Methodology: Choe J, Kang J, Park S.

Software: Choe J, Kang J, Cho JY.

Validation: Cho JH, Kim HB.

Investigation: Kang J, Cho JH, Kim HB.

Writing - original draft: Lee JJ, Choe J, Song M.

Writing - review \& editing: $\mathrm{Cho} \mathrm{JH}, \mathrm{Kim} \mathrm{HB}$, Song M.

Ethics approval and consent to participate The experimental protocol for this research was reviewed and approved by the Institutional Animal Care and Use Committee of Chungnam National University, Daejeon, Korea (approval \#CNU-00910). mance that has been used for decades [1,2]. Therefore, the swine industry has been used antibiotic growth promoters (AGP) which has two major impacts; growth promoting and disease prevention $[1,3]$. However, there is a potential risk and a concern by the society about the emergence of antimicrobial resistance in human pathogenic bacteria and their transmission into the human population by the abuse of AGP [1-4]. Thus the use of AGP in animal diets has been banned or reduced internationally and at the same time alternatives for AGP have been increasingly demanded. Moreover, the cost of main ingredients in swine diets, such as soybean meal and corn, have been remarkably increased due to the competition among animal feed, human food, and biofuel industries [5-8]. Especially, soybean meal which is one of main protein sources for swine, but unfortunately it contains various anti-nutritional factors (ANFs) that can inhibit protein utilization by pigs [9-11].

Potential solutions for the issues mentioned above are strongly required to replace the AGP without the risk regarding antimicrobial resistant microbes and to improve the utilization of protein and other nutrients in pig diets efficiently. Inclusion of exogenous enzyme in pig diets is one of plausible strategies for improvement of nutrient utilization efficiency $[12,13]$. Among the exogenous enzymes available, dietary protease (PRO) is an enzyme to catalyze the hydrolysis of proteins with ANFs to small peptides or amino acids and is generally used as a part of enzyme cocktails [14-19] or used as a mono-component protease [20-22] in non-ruminant diets. Previous studies reported the supplementation of $\mathrm{PRO}$ which improved growth performance and nutrient digestibility at various stages of different age of pigs [14,17,22-24], but the beneficial effects of PRO on pig performance and nutrient digestibility have not been further confirmed particularly at the latest pig growth period. Therefore, the objective of this study was to verify whether addition of PRO could improve growth performance and nutrient digestibility of growing-finishing pigs.

\section{MATERIALS AND METHODS}

The experimental protocol for this study was reviewed and approved by the Institutional Animal Care and Use Committee of Chungnam National University, Daejeon, Korea. This study was performed at the research facility of Chungnam National University.

\section{Experimental design, animals, and diets}

A total of eighty-four pigs [Duroc $\times$ (Landrace $\times$ Yorkshire); average initial body weight $(\mathrm{BW})$ of $25.3 \pm 2.16 \mathrm{~kg}]$ were used and randomly assigned to three diets $(7$ replicates/treatment, 2 barrows and 2 gilts/replicate) in a randomized complete block design (block = sex). The diets were as follows; (1) positive control (PC) as a typical growing-finishing diet based on corn and soybean meal, (2) PC added with $0.015 \%$ of PRO (PCPRO), and (3) negative control (NC) added with $0.015 \%$ of PRO (NCPRO) (Table 1). The NC had a lower level of crude protein compared with PC. The PRO was a commercial product (Ronozyme ${ }^{\circledR}$ ProAct, DSM Nutritional Products, Kaiseraugst, Switzerland) that contained 75,000 protease units/g derived from Nocardiopsis prasina produced in Bacillus licheniformis. There were 2 experimental periods which consisted of 6 weeks of growing period followed by a 5 weeks finishing period. All pigs were housed in an environmentally controlled room with free access to feed and water during the overall experimental period.

\section{Data and sample collection}

The BW of pigs and the amount of feed offered and feed residual in each pen were weighed at the initial and end of each experiment period (growing and finishing periods). Growth performance [average daily gain (ADG), average daily feed intake (ADFI), and feed efficiency (G:F ratio, gainto-feed ratio)] was measured throughout. In the last week of each experimental period, a respective 
Table 1. Composition of experimental diets for growing-finishing pigs (as-fed basis)

\begin{tabular}{|c|c|c|c|c|}
\hline \multirow{3}{*}{ Item } & \multicolumn{4}{|c|}{ Experimental diets } \\
\hline & \multicolumn{2}{|c|}{ Growing } & \multicolumn{2}{|c|}{ Finishing } \\
\hline & PC & NC & PC & NC \\
\hline \multicolumn{5}{|l|}{ Ingredients (\%) } \\
\hline Corn $(8 \%)$ & 46.34 & 46.58 & 49.62 & 54.80 \\
\hline Soybean meal (44\%) & 18.00 & 17.70 & 10.30 & 9.30 \\
\hline Wheat (10\%) & 14.60 & 15.00 & 15.60 & 11.00 \\
\hline DDGS & 9.70 & 11.10 & 14.30 & 15.60 \\
\hline Rapeseed meal & 4.00 & 4.10 & 5.50 & 5.60 \\
\hline Full fat soya & 2.70 & 0.50 & 1.00 & 0.60 \\
\hline Tallow & 1.20 & 1.50 & 0.80 & 0.70 \\
\hline Mono-dicalcium phosphate & 0.90 & 0.90 & 0.47 & 0.49 \\
\hline Limestone & 1.20 & 1.30 & 1.30 & 1.30 \\
\hline Salt & 0.36 & 0.35 & 0.28 & 0.27 \\
\hline Vitamin-mineral premix ${ }^{1)}$ & 0.30 & 0.30 & 0.30 & 0.30 \\
\hline L-Lysine-HCl & 0.40 & 0.40 & 0.36 & 0.35 \\
\hline DL-Methionine & 0.13 & 0.12 & 0.05 & 0.03 \\
\hline L-Threonine & 0.14 & 0.12 & 0.11 & 0.09 \\
\hline L-Tryptophan & 0.03 & 0.03 & 0.01 & 0.01 \\
\hline Total & 100 & 100 & 100 & 100 \\
\hline \multicolumn{5}{|l|}{ Calculated composition } \\
\hline Metabolizable energy (Mcal/kg) & 3.21 & 3.21 & 3.16 & 3.16 \\
\hline Crude protein (\%) & 18.43 & 17.93 & 16.53 & 16.18 \\
\hline Lysine (\%) & 1.15 & 1.10 & 0.94 & 0.90 \\
\hline Methionine (\%) & 0.43 & 0.41 & 0.33 & 0.31 \\
\hline Cysteine (\%) & 0.29 & 0.27 & 0.28 & 0.26 \\
\hline $\mathrm{Ca}(\%)$ & 0.76 & 0.76 & 0.72 & 0.72 \\
\hline $\mathrm{P}(\%)$ & 0.58 & 0.58 & 0.53 & 0.53 \\
\hline
\end{tabular}

1)Provided per kilogram of diet: vitamin A, $12,000 \mathrm{IU}$; vitamin $\mathrm{D}_{3}, 2,500 \mathrm{IU}$; vitamin E, $30 \mathrm{IU}$; vitamin $\mathrm{K}_{3}, 3 \mathrm{mg}$; D-pantothenic acid, $15 \mathrm{mg}$; nicotinic acid, $40 \mathrm{mg}$; choline, $400 \mathrm{mg}$; and vitamin $\mathrm{B}_{12}, 12 \mu \mathrm{g}$; Fe, $90 \mathrm{mg}$ from iron sulfate; $\mathrm{Cu}, 8.8 \mathrm{mg}$ from copper sulfate; $\mathrm{Zn}, 100 \mathrm{mg}$ from zinc oxide; Mn, $54 \mathrm{mg}$ from manganese oxide; I, $0.35 \mathrm{mg}$ from potassium iodide; Se, $0.30 \mathrm{mg}$ from sodium selenite.

PC, positive control; NC, negative control.

experimental diet containing $0.2 \%$ of chromic oxide as an indigestible marker was provided during that week. Fecal samples from randomly selected two pigs per pen were collected daily by rectal palpation for the last $3 \mathrm{~d}$ after $4 \mathrm{~d}$ adaptation period. Diet samples were collected from each batch of manufactured feed and subsequently pooled and stored at $-20^{\circ} \mathrm{C}$ until analysis. Diet and fecal samples were dried in a forced-air drying oven at $60^{\circ} \mathrm{C}$ and ground using a cyclone mill (Foss Tecator Sycltec 1093, Hillerød, Denmark) before analysis.

In the last day of the experiment, all feed was withdraw 4 hours previous to all pigs being transported from the farm to the nearest local commercial slaughterhouse. The slaughter procedure and carcass characteristics measurements were performed under the supervision of the Korea Institute for Animal Products Quality Evaluation. The pigs were washed with water for reducing stress. To all pigs, water was freely accessible during lairage, and were allowed to rest for about 4 hours. The final BW of each pig was noted and processed with conventional slaughter process with the electrical stunning and scalding-singeing. 


\section{Sample analyses and measurements}

Diet and fecal samples were analyzed for dry matter (DM) [25], crude protein (CP) [25], gross energy (GE) using a bomb calorimeter (Parr 1281 Bomb Calorimeter, Parr Instrument Co., Moline, IL, USA), and chromium contents using an absorption spectrophotometer (Hitachi Z-5000 Absorption Spectrophotometer, Hitachi High-Technologies Co., Tokyo, Japan). Apparent total tract digestibility (ATTD) of DM, CP, and GE of growing and finishing pigs was calculated based on Stein et al. [26]. The dressing percentage was calculated by comparing final live BW and hot carcass weight. After splitting, the backfat thickness was directly measured between 11th and 12th thoracic vertebras and between the last thoracic vertebras as well as the 1 st lumbar vertebra. The average of two measurements was expressed as a backfat thickness for each pig.

\section{Statistical analysis}

All data was analyzed with the PROC General Linear Models (GLM) of SAS (SAS Inst., Cary, NC, USA). The pen was used as an experimental unit. The statistical model for growth performance, nutrient digestibility, and carcass characteristics included dietary treatments as a fixed effect and sex as a covariate. The results are presented as a mean \pm standard error of the mean. Statistical significance and tendency were considered at $p<0.05$ and $0.05 \leq p \leq 0.10$, respectively.

\section{RESULTS AND DISCUSSION}

Pigs fed PCPRO and NCPRO had higher ADG and G:F ratio during growing $(p<0.10)$ and finishing $(p<0.05)$ periods than those fed PC (Table 2). Similarly, the PCPRO and NCPRO

Table 2. Effects of dietary protease on growth performance of growing-finishing pigs ${ }^{1)}$

\begin{tabular}{|c|c|c|c|c|c|}
\hline \multirow{2}{*}{ Item } & \multicolumn{3}{|c|}{ Treatments } & \multirow{2}{*}{ SEM } & \multirow{2}{*}{$p$-value } \\
\hline & PC & PCPRO & NCPRO & & \\
\hline \multicolumn{6}{|c|}{ Growing period ( 6 weeks after weaning period) } \\
\hline Final body weight (kg) & 63.96 & 65.23 & 65.07 & 1.29 & 0.756 \\
\hline$A D G(k g / d)$ & $0.920^{\mathrm{a}}$ & $0.953^{b}$ & $0.943^{b}$ & 0.01 & 0.099 \\
\hline \multicolumn{6}{|c|}{ Finishing period ( 5 weeks after growing period) } \\
\hline Initial body weight $(\mathrm{kg})$ & 63.96 & 65.23 & 65.07 & 1.29 & 0.756 \\
\hline Final body weight $(\mathrm{kg})$ & 97.50 & 100.41 & 100.89 & 1.68 & 0.324 \\
\hline$A D G(k g / d)$ & $0.958^{\mathrm{a}}$ & $1.005^{\mathrm{b}}$ & $1.023^{b}$ & 0.02 & 0.045 \\
\hline Initial body weight (kg) & 25.34 & 25.20 & 25.45 & 0.77 & 0.974 \\
\hline Final body weight $(\mathrm{kg})$ & 97.50 & 100.41 & 100.89 & 1.68 & 0.324 \\
\hline $\mathrm{ADG}(\mathrm{kg} / \mathrm{d})$ & $0.937^{\mathrm{a}}$ & $0.977^{\mathrm{ab}}$ & $0.980^{b}$ & 0.01 & 0.098 \\
\hline ADFI (kg/d) & 2.852 & 2.756 & 2.707 & 0.07 & 0.356 \\
\hline G:F ratio $(\mathrm{kg} / \mathrm{kg})$ & $0.329^{a}$ & $0.354^{b}$ & $0.362^{b}$ & 0.01 & 0.015 \\
\hline
\end{tabular}

${ }^{1}$ Each value is the mean value of 7 replicates (4 pigs/replicate).

a,b Means with different superscripts within the same row differ $(p<0.10)$.

PC, positive control; PCPRO, positive control $+0.015 \%$ of dietary protease; NCPRO, negative control $+0.015 \%$ of dietary protease; SEM, standard error of mean; $A D G$, average daiIy gain; $A D F I$, average daily feed intake; $G: F$ ratio, gain-to-feed ratio. 
increased ADG $(p<0.10)$ and G:F ratio $(p<0.05)$ during overall experimental period compared with PC. These results are consistent with the results from previous studies reported that PRO improved growth rate of growing-finishing pigs [20,21,27]. These beneficial effects of PRO may be contributed by improved availability of more degraded protein with improved apparent ileal $\mathrm{N}$ digestibility reduced ANFs by PRO in pig diets [22,28-30]. The beneficial effect of mono-component protease on pig performance which was observed in this study was also reported by the work done by O'Doherty and Forde [27]. Those workers found improvements in the weight gain (0.862 vs $0.887 \mathrm{~kg} /$ day) of growing and finishing pigs. Generally, weaned pigs have a low activity of digestive enzymes in the stomach and pancreatic epithelium tissue, but growing or finishing pigs have a more developed digestive system [31-33]. Supplementation of dietary enzymes including PRO was complementary to the endogenous digestive systems. PRO was able to degrade certain nutrients that were not well digested by endogenous enzymes secreted from the animal digestive systems. Similarly, the application of PRO in the diets of animals may be able to neutralize certain ANFs, resulting in an increase of nutrient digestibility and utilization efficiency [14,28,31].

Pigs fed PCPRO and NCPRO had higher ATTD of CP during growing period $(p<0.05)$ and ATTD of $\mathrm{CP}$ and GE during finishing period $(p<0.05)$ than those fed PC (Table 3). These results are consistent with previous work that showed the improvement of nutrient digestibility of growing-finishing pigs [29,30,34], but did not show an improvement of growth performance of pigs fed PRO. However, some studies did not observe the positive effects of PRO on nutrient digestibility of growing pigs, but found only improvement of growth performance of pigs fed PRO [20-22]. The beneficial impact of PRO in present study may be related to more opportunities for pigs to better utilize more hydrolyzed protein by PRO in the experimental diets, resulting in the improvement of both growth performance and nutrient digestibility.

There were no significant differences between treatments on carcass characteristics of pigs by addition of PRO in the pig diets (Table 4). Similar results were observed in previous studies [20,21,35], but other previous work did show changed of carcass characteristics of pigs when PRO was added in the diets $[35,36]$. The inconsistent results may be due to different type of PRO used and the conditions and stages of pig age when PRO were added into the diets. Future research is needed to investigate in detail amino acid digestibility profile and to verify whether PRO can modify carcass characteristics of pigs.

Table 3. Effects of dietary protease on apparent total tract digestibility of growing-finishing pigs ${ }^{1)}$

\begin{tabular}{|c|c|c|c|c|c|}
\hline \multirow{2}{*}{ Item } & \multicolumn{3}{|c|}{ Treatments } & \multirow{2}{*}{ SEM } & \multirow{2}{*}{$p$-value } \\
\hline & PC & PCPRO & NCPRO & & \\
\hline \multicolumn{6}{|c|}{ Growing period (6 weeks after weaning period) } \\
\hline $\mathrm{DM}(\%)$ & 73.77 & 80.57 & 80.22 & 2.57 & 0.487 \\
\hline $\mathrm{CP}(\%)$ & $69.61^{\mathrm{a}}$ & $76.33^{b}$ & $77.53^{\mathrm{b}}$ & 2.21 & 0.046 \\
\hline GE $(\%)$ & 72.68 & 79.63 & 79.26 & 2.46 & 0.327 \\
\hline \multicolumn{6}{|c|}{ Finishing period ( 5 weeks after growing period) } \\
\hline $\mathrm{DM}(\%)$ & 78.33 & 85.86 & 83.36 & 1.93 & 0.108 \\
\hline $\mathrm{CP}(\%)$ & $74.26^{\mathrm{a}}$ & $83.61^{\mathrm{b}}$ & $83.36^{b}$ & 1.99 & 0.041 \\
\hline GE $(\%)$ & $74.86^{\mathrm{a}}$ & $83.84^{\mathrm{b}}$ & $83.99^{b}$ & 2.06 & 0.043 \\
\hline
\end{tabular}

${ }^{11}$ Each value is the mean value of 7 replicates (2 pigs/replicate).

a,b Means with different superscripts within the same row differ significantly $(p<0.05)$.

PC, positive control; PCPRO, positive control $+0.015 \%$ of dietary protease; NCPRO, negative control $+0.015 \%$ of dietary protease; SEM, standard error of mean; DM, dry matter; $\mathrm{CP}$, crude protein; $\mathrm{GE}$, gross energy. 
Table 4. Effects of dietary protease on carcass characteristics of growing-finishing pigs ${ }^{1)}$

\begin{tabular}{|c|c|c|c|c|c|}
\hline \multirow{2}{*}{ Item } & \multicolumn{3}{|c|}{ Treatments } & \multirow{2}{*}{ SEM } & \multirow{2}{*}{$p$-value } \\
\hline & PC & PCPRO & NCPRO & & \\
\hline Final live body weight $(\mathrm{kg})$ & 97.50 & 100.41 & 100.89 & 1.68 & 0.324 \\
\hline Hot carcass weight $(\mathrm{kg})$ & 87.71 & 87.56 & 89.10 & 1.18 & 0.603 \\
\hline Dressing percentage (\%) & 78.76 & 78.65 & 78.69 & 0.08 & 0.571 \\
\hline Backfat depth (mm) & 21.94 & 21.01 & 21.78 & 0.69 & 0.605 \\
\hline
\end{tabular}

${ }^{1)}$ Each value is the mean value of 7 replicates; The growing-finishing period was 11 weeks after weaning.

PC, positive control; PCPRO, positive control $+0.015 \%$ of dietary protease; NCPRO, negative control $+0.015 \%$ of dietary protease; SEM, standard error of means.

\section{CONCLUSION}

The present study indicates supplementation of PRO in diets improved growth performance and protein digestibility of growing-finishing pigs.

\section{REFERENCES}

1. Dibner JJ, Richards JD. Antibiotic growth promoters in agriculture: history and mode of action. Poult Sci. 2005;84:634-43.

2. Fouhse JM, Zijlstra RT, Willing BP. The role of gut microbiota in the health and disease of pigs. Anim Front. 2016;6:30-6.

3. Brown K, Uwiera RRE, Kalmokoff ML, Brooks SPJ, Inglis GD. Antimicrobial growth promoter use in livestock: a requirement to understand their modes of action to develop effective alternatives. Int J Antimicrob Agents. 2017;49:12-24.

4. Modi CM, Mody SK, Patel HB, Dudharta GB, Kumar A, Sheikh TJ. Growth promoting use of antimicrobial agents in animals. J Appl Pharm Sci. 2011;01:33-6.

5. Kim J, Seo J, Kim W, Yun HM, Kim SC, Jang Y, et al. Effects of palm kernel expellers on productive performance, nutrient digestibility, and white blood cells of lactating sows. Asian-Australas J Anim Sci. 2015;28:1150-4.

6. Kim S, Kim B, Kim Y, Jung S, Kim Y, Park J, et al. Value of palm kernel co-products in swine diets. Korean J Agric Sci. 2016;43:761-8.

7. Hoffman LA, Baker AJ. Estimating the substitution of distillers' grains for corn and soybean meal in the U.S. feed complex. Washington, DC: United States Department of Agriculture; 2011. Report No.: FDS-11-I-01.

8. Lawrence JD, Mintert J, Anderson JD, Anderson DP. Feed grains and livestock: impacts on meat supplies and prices. Choices. 2008;23:11-5.

9. Florou-Paneri P, Christaki E, Giannenas I, Bonos E, Skoufos I, Tsinas A, et al. Alternative protein sources to soybean meal in pig diets.J Food Agric Environ. 2014;12:655-60.

10. Min BJ, Cho JH, Chen YJ, Kim HJ, Yoo JS, Wang Q, et al. Effects of replacing soy protein concentrate with fermented soy protein in starter diet on growth performance and ileal amino acid digestibility in weaned pigs. Asian-Australas J Anim Sci. 2009;22:99-106.

11. Anderson RL, Rackis JJ, Tallent WH. Biologically active substances in soy products. In: Wilcke HL, Hopkins DT, Waggle DH, editors. Soy protein and human nutrition. New York, NY: Academic press; 1979. p. 209-33.

12. Park S, Kim B, Kim Y, Kim S, Jang K, Kim Y, et al. Nutrition and feed approach according to pig physiology. Korean J Agric Sci. 2016;43:750-60.

13. Adeola O, Cowieson AJ. Board-invited review: opportunities and challenges in using exoge- 
nous enzymes to improve nonruminant animal production.J Anim Sci. 2011;89:3189-218.

14. Zuo J, Ling B, Long L, Li T, Lahaye L, Yang C, et al. Effect of dietary supplementation with protease on growth performance, nutrient digestibility, intestinal morphology, digestive enzymes and gene expression of weaned piglets. Anim Nutr. 2015;1:276-82.

15. Kim Y, Baek J, Jang K, Kim J, Kim S, Mun D, et al. Effects of dietary enzyme cocktail on growth performance, intestinal morphology, and nutrient digestibility of weaned pigs. Korean J Agric Sci. 2017;44:513-8.

16. Kang J, Cho J, Jang K, Kim J, Kim S, Mun D, et al. Effects of dietary enzyme cocktail on diarrhea and immune responses of weaned pigs. Korean J Agric Sci. 2017;44:525-30.

17. Kim SK, Cho MW, Kim JS, Jang KB, Kim SA, Mun DY, et al. Effects of eco-friendly multi-enzyme on growth performance, intestinal morphology, and nutrient digestibility of weaned pigs. Korean J Org Agric. 2018;26:141-9.

18. Min YJ, Kim JS, Kim SA, Jang KB, Mun DY, Kim BH, et al. Effects of eco-friendly multi-enzyme on diarrhea and immune response of weaned pigs. Korean J Org Agric. 2018;26:151-61.

19. Min Y, Choi Y, Choe J, Kim Y, Jeong Y, Kim D, et al. Effects of dietary mixture of protease and probiotics on growth performance, blood constituents, and carcass characteristics of growing-finishing pigs.J Anim Sci Technol. 2019;61:272-7.

20. Choe J, Kim KS, Kim HB, Park S, Kim J, Kim S, et al. Effect of protease on growth performance and carcass characteristics of growing-finishing pigs. S Afr J Anim Sci. 2017;47:697703.

21. Min Y, Choi Y, Kim Y, Jeong Y, Kim D, Kim J, et al. Effects of protease supplementation on growth performance, blood constituents, and carcass characteristics of growing-finishing pigs.J Anim Sci Technol. 2019;61:234-8.

22. Park S, Lee JJ, Yang BM, Cho JH, Kim S, Kang J, et al. Dietary protease improves growth performance, nutrient digestibility, and intestinal morphology of weaned pigs.J Anim Sci Technol. 2020;62:21-30.

23. Yin YL, Baidoo SK, Jin LZ, Liu YG, Schulze H, Simmins PH. The effect of different carbohydrase and protease supplementation on apparent (ileal and overall) digestibility of nutrients of five hulless barley varieties in young pigs. Livest Prod Sci. 2001;71:109-20.

24. Yin YL, Deng ZY, Huang HL, Li TJ, Zhong HY. The effect of arabinoxylanase and protease supplementation on nutritional value of diets containing wheat bran or rice bran in growing pig. J Anim Feed Sci. 2004;13:445-61.

25. AOAC [Association of Official Analytical Chemists] International. Official methods of analysis of AOAC International. Gaithersburg, MD: AOAC International; 2005.

26. Stein HH, Seve B, Fuller MF, Moughan PJ, de Lange CFM. Invited review: Amino acid bioavailability and digestibility in pig feed ingredients: terminology and application. J Anim Sci. 2007;85:172-80.

27. O'doherty JV, Forde S. The effect of protease and alpha-galactosidase supplementation on the nutritive value of peas for growing and finishing pigs. Ir Agric Food Res. 1999;217-26.

28. Cowieson AJ, Roos FF. Toward optimal value creation through the application of exogenous mono-component protease in the diets of non-ruminants. Anim Feed Sci Tech. 2016;221:33140.

29. O'Shea CJ, Mc Alpine PO, Solan P, Curran T, Varley PF, Walsh AM, et al. The effect of protease and xylanase enzymes on growth performance, nutrient digestibility, and manure odour in grower-finisher pigs. Anim Feed Sci Tech. 2014;189:88-97.

30. Pan L, Zhao PF, Yang ZY, Long SF, Wang HL, Tian QY, et al. Effects of coated compound proteases on apparent total tract digestibility of nutrients and apparent ileal digestibility of ami- 
no acids for pigs. AsianAustralas J Anim Sci. 2016;29:1761-7.

31. Hedemann MS, Jensen BB. Variations in enzyme activity in stomach and pancreatic tissue and digesta in piglets around weaning. Arch Anim Nutr. 2004;58:47-59.

32. Ngoc TTB, Len NT, Ogle B, Lindberg JE. Influence of particle size and multi-enzyme supplementation of fibrous diets on total tract digestibility and performance of weaning $(8-20 \mathrm{~kg})$ and growing (20-40 kg) pigs. Anim Feed Sci Technol. 2011;169:86-95.

33. Zhang GG, Yang ZB, Wang Y, Yang WR, Zhou HJ. Effect of dietary supplementation of muti-enzyme on growth performance, nutrient digestibility, small intestinal digestive enzyme activities, and large intestinal selected microbiota in weanling pigs. J Anim Sci. 2014;92:2063-9.

34. Ji F, Casper DP, Brown PK, Spangler DA, Haydon KD, Pettigrew JE. Effects of dietary supplementation of an enzyme blend on the ileal and fecal digestibility of nutrients in growing pigs.J Anim Sci. 2008;86:1533-43.

35. Stephenson EW, DeRouchey JM, Escobar J, Woodworth JC, Tokach MD, Goodband RD, et al. Effects of a novel protease enzyme (CIBENZA DP100) on finishing pig growth performance and carcass characteristics. Kans Agric Exp Stn Res Rep. 2014;69-76.

36. Wang D, Zeng Z, Piao X, Li P, Xue L, Zhang Q, et al. Effects of keratinase supplementation of corn-soybean meal based diets on apparent ileal amino acid digestibility in growing pigs and serum amino acids, cytokines, immunoglobulin levels and loin muscle area in nursery pigs. Arch Anim Nutr. 2011;65:290-302. 